\title{
Justifying Jihad: US politics, propaganda and the Afghan Mujahedeen, 1979-1989
}

\section{Jacqueline Fitzgibbon}

School of History, UCC

'I believe that our public diplomacy represents a powerful force, perhaps the most powerful force at our disposal, for shaping the history of the world.' (Ronald Reagan)

\section{Introduction}

The Afghan resistance to the Soviet occupation began in 1979 and culminated in the withdrawal of Soviet forces a decade later and was, many believe, instrumental in the disintegration of the Soviet Union shortly after. The administration of President Ronald Reagan (1981-1989), many influential members of Congress and vocal right-wing groups, wholeheartedly supported the anti-government and anti-Soviet resistance efforts of the Afghan mujahedeen. These insurgents were recast as 'freedom fighters' and supplied with military hardware, training and economic aid by the US, Pakistan, China, Iran and Saudi Arabia. Furthermore, the Reagan administration undertook a major public diplomacy programme to promote this view of the mujahedeen to justify American support and ensure that the rest of the world, including Afghanis, saw the rebels in the same light. In the 1990s, some of these former 'freedom fighters' used the skills they learned during this period in Afghanistan to create a deadly terrorist organisation, al Qaeda, which carried out the ultimate 'propaganda of the deed' the destruction of New York's famed Twin Towers on 11th September 2011.

\section{Public diplomacy and propaganda in US Foreign Policy}

As the aftermath of World War Two segued into the beginning of the Cold War, former allies and now emergent superpowers, the US and USSR, were soon locked in a competition for dominance in the international system. Direct military confrontation would lead to nuclear annihilation and so winning 'hearts and minds', the psychological battle for the ideological allegiance of the world's peoples, became a major focus of US foreign policy. Public diplomacy and propaganda, as well as psychological operations and rhetoric, were now considered vital instruments in the pursuit of US foreign policy aims. US administrations framed the public presentation of foreign policy decisions with references to the political and cultural ideals of the United States of America, such as self-determination, 
liberty and democracy. As America's past and present were perceived to be rooted in these values, it was axiomatic that its foreign policy would seek to propagate them.

The Truman Administration's (1945-1953) foreign policy doctrine called on Americans to support 'free peoples who are resisting subjugation' in Greece with substantial military and economic aid. Although these 'free people' were defending the repressive Greek monarchy they were also opposing communism and, therefore in the administration's view, containing Soviet influence. 'Freedom' was reduced to a concept - the antithesis of communism - rather than a reflection of the internal political conditions in Greece.

President Eisenhower (in office from 1953 to 1961) considered the 'P-factor' (psychological factor) of vital importance to US foreign policy, and established, in 1953, the United States Information Agency (USIA), the Public Diplomacy agency of the US government. However, he warned that 'audiences would be more receptive to the American message if they were kept from identifying it as propaganda'. The US was reluctant to associate its official information and communication activities with the term propaganda. This was partly due to the term's perceived negative connotations and partly because of America's inherent sense of exceptionalism: the US belief that it is unique amongst nations, an exemplar for others, and that its values were, and are, universal. As a result, the term propaganda was avoided by the US in describing its dialogue with foreign publics or its use of information as a military tactic. Instead, words such as public diplomacy, psychological operations and information warfare, which some consider to be merely euphemisms for propaganda, were popularised. In any event, during the Cold War, successive US administrations sought to manage public perceptions and information in the pursuit of foreign policy goals.

President Reagan, a former actor and an engaging orator, was a keen advocate of public diplomacy. Soon after taking office, President Reagan wrote that his administration was 'determined to stop losing the propaganda war'. One of the administration's main foreign policy strategies, the Reagan Doctrine, sought to 'rollback' communism by backing right-wing anti-communist insurgents whose political agendas were often extremist and reactionary. The strategy focussed on Third World, peripheral states such as Afghanistan, Nicaragua, Angola and Cambodia. To help achieve these aims, the USIA was strengthened and re-invigorated under the Reagan Administration to initiate a 'new war of ideas and values against communism'. The people of Afghanistan would become entangled in this ideological battle.

\section{Public diplomacy and Afghanistan}

The administration engaged in public diplomacy in a large scale, coherent manner both within South Central Asia and back in the 'West' to create 'freedom fighters' from rebels regardless of their extremist views, questionable human rights records or involvement in 
drug smuggling. To this end various members of the administration used public diplomacy to build support for the doctrine. The USIA instructed the Voice of America, the agency's broadcasting arm, not to use the terms 'rebels' or 'anti-government guerrillas' to describe the Afghan mujahedeen but rather 'patriots', 'nationalists' or 'freedom fighters' which have more positive associations. The necessity of creating support for the doctrine (and those it supported) within the domestic sphere was one of the 'lessons' drawn from the effects of negative US media coverage of the Vietnam War which the administration took to heart.

The USIA was involved on a number of levels in creating and managing public diplomacy/propaganda in relation to Afghanistan, and a special task force on Afghanistan was formed to keep the war in the public consciousness. The agency set up the Afghan Media Project to train mujahedeen as journalists, photographers and video-cameramen in Peshawar, on the Pakistan/Afghanistan border, to report from inside Afghanistan and distribute this 'news' worldwide. The agency also organised conferences, presentations by academics, Voice of America broadcasts on the war, situation reports, briefings to journalists and documentaries on Afghanistan.

The stance of the American media was generally supportive reflecting the administration's (and Congress') position. In a 1984, editorial the Washington Post stated 'The fight for freedom in Afghanistan is an awesome spectacle and deserves generous tribute', while in 1986 the Los Angeles Times offered this judgement 'The Afghan guerrillas have earned the admiration of the American people for their courageous struggle...The rebels deserve unstinting American political support, and within the limits of prudence, military hardware'. Whether the media based their reporting on independent investigation or were influenced by information filtered through official channels will be investigated during the course of my research.

\section{The archives}

My dissertation focuses on investigating the public diplomacy/propaganda campaign of the Reagan Administration, the efforts of some members of Congress to aid the mujahedeen and the strategies of conservative groups and think-tanks to influence policy towards Afghanistan. This will require research at the Reagan Presidential Library in California. The archives there contain fifty million pages of documents relating to the Reagan presidency, 1.6 million photographs and tens of thousands of audio and video tapes so careful planning to pinpoint what I need will be required before I visit or I may never re-emerge!

I also intend to investigate the Afghan programmes of the USIA, to assess their impact on public perception and discourse surrounding the conflict in Afghanistan. This will necessitate a visit to Washington, where the agency's archives are located. Whilst there, I will also pay a visit to the Library of Congress on Capitol Hill, which is the largest library in 
the world. An examination of the congressional record, congressional hearings and public statements of members of Congress will establish how successful the legislature was in shaping the public debate on aid to the mujahedeen and in affecting administration policies. In addition, my dissertation will assess the influence of the 'New Right' conservative groups and think-tanks, many of which were avidly pro-mujahedeen, on the Administration, Congress and on public discourse through analysis of reports and papers issued by these organisations seeking to influence policy. Unearthing this information may be less straightforward, as some of these are private rather than public institutions and so their archives may not be readily available to researchers.

\section{Conclusion}

This research should illuminate why the Reagan Administration, various members of Congress and other private advocacy groups and think-tanks sought to characterise their support of the mujahedeen as synonymous with support for abiding US political and cultural ideals, and the extent to which public diplomacy and propaganda were utilised to this end. It will also seek to explain why the US media and public so readily accepted this narrative. It will also endeavour to establish how successful this public diplomacy exercise was in influencing the media and shaping public opinion and what impact it ultimately had on the course of the war in Afghanistan. While this research focuses on the Reagan Administration and Afghanistan in the 1980s, it is of continuing relevance, as the US is still a major world power seeking to actively influence international events by using both hard (military or economic) and soft (public diplomacy) power. While US public diplomacy offers 'universal' ideals as a guide for conduct in international affairs, US foreign policy often only seeks to ensure their application when in the American national interest. President Obama vocally supported rebels in Libya seeking to overthrow US nemesis Muammar Gaddafi but remained silent when revolutionaries with similar democratic aspirations were crushed, with Saudi military aid (a US ally), in Bahrain (a US ally). Such selectivity serves to highlight the relevance of exploring and detailing public diplomacy as a tool of foreign policy in today's world.

Jacqueline Fitzgibbon is a first-year PhD student in the School of History under the supervision of Professor David Ryan. 